\title{
ARTICLES \\ THE CONCEPT OF THE CENTRE IN ISLAM
}

\author{
Hamza Zeghlache*
}

\begin{abstract}
This article argues that any exploration of the textual representations of place, space, and landscape in the pre-modern Arabic-Islamic tradition requires grasping the cultural conception of the centre reflecting developments from a long historical and textual tradition of cosmological ideas found in the work of Yāqūt's (d. 1229) Mu 'jam al-buldān, and al-Suyūțī's (d. 1505) al-Hay'at al-sanīyah fí 'l-hay'at al-sunniyah. It further explores the complex construct of the centre in Islam within the context of its relation to the origin of Islamic cities by considering it an organising principle of the mental and moral disposition for spiritual and physical orientation.
\end{abstract}

To the memory of Professor Mohammed Arkoun (1928-2010)

\section{Introduction}

The human use of space and the values with which society imbues spatial relations involve a collective representation of the world. Mircea Eliade in his The Sacred and the Profane states that "[i]f the world is to be lived in, it must be founded". To understand how a society founds its world is to understand the cultural process governing the system of ideas a society has of itself and the universe surrounding it. An exploration of the representation of the world as an image must begin with grasping the cluster of governing ideas which are developments with a long historical and textual tradition, and which are deeply rooted within society. At the core of such clusters is a coherent integral image of the world. The form and meaning of such an image has a collective origin arising from society's prescriptive configuration of ideal purposes, values, and beliefs.

* Hamza Zeghlache is Professor of Islamic Architecture at the University of Setif, Algeria. This article is a part of an interdisciplinary research project in architecture and anthropology that has received financial support from the Wenner Gren Foundation for Anthropological Research, New York, and the Department of Anthropology of the University of Virginia, United States. The author would like to express his gratitude for this support. 
This configuration is an organising principle operating in everyday life as acknowledged social convention, which gets absorbed into the realm of social values thereafter. These social values are consciously or unconsciously codified in elaborate rituals influencing ways of thinking and the perceiving and categorising of experiences.

Thus, the world image as conceived by the Islamic cultural tradition involves a traditional worldview (or ideology), the complex of ideas about man, his existence in nature, society, and cosmos, his relation with mundane things and forces, as well as with mystical beings and forces, and his ultimate reality. Characterised by the interrelatedness of the universe and the world of men, this worldview forms a complex system of symbolic classification of apparently unrelated elements (non-social things). Such an integral system of beliefs in the traditional world is interwoven with and communicated to the people of the cities. This process makes things resonate symbolically as they become associated with the social values of a society which was achieved by man's attempts to create a starting point - the centre of the world (Figure 1). Therefore, a 'spatial' configuration characterised by a central element is used as an organising principle of mental and moral dispositions for future spiritual and physical orientation. Such mental and moral dispositions comprise the components of human images and constitute their inner world. "For such images, they reappear implicitly (or explicitly) in the way man reassures himself when feeling adrift."”

\section{The Concept of the Centre of the World}

The way society conceptualises and perceives space is a projection of the image of itself into spatial arrangement. In Islam, people interpret this system in religious terms and project images of the integral components of the world as derived from religious teaching. The most basic of these projected images usually revolve around such conceptions as earth, heaven, and underworld, or what Eliade calls the "system of the world". Such logical classifications of religious-primordial concepts are made so they may bring their life activities and spatial arrangements into harmony with the universe. In order to structure the world, man uses a process in which he projects his inner vision of the world onto the outside world through various idiosyncratic and cultural symbols. "Everywhere the visible seemed to reflect the invisible", or as von Simson puts it, "[i]t is this process by which the symbolic instinct transformed vision into architectural form". ${ }^{3}$

As a result of this process, a communication between man and space develops in a form of a resonance resembling musical polyphony. An audible musical melody requires at least two different strings of notes performed synchronically together. ${ }^{4}$ By analogy, the resonance or the 'complicity between man and space' requires at least two elements - the space in its physical shell on the one hand, and the 
meaning that man gives to it on the other. This resonance includes the cosmological symbolism that man uses in constructing on the earth a reduced version of his encompassing universe. This process brings into association and harmony the natural and supernatural world. In other words, "[v]isible and audible harmonies are actually imitations of that harmony and proportion which the blessed will enjoy in the world to come". ${ }^{5}$ This association is achieved by starting at a point with which man participates in the symbolism of the centre of the world. According to Eliade, this process of man's imitation of the celestial archetype is as a repetition of the paradigmatic work of gods on earth, and this resemblance is seen as a sacred experience. As Wheatley puts it, "only the sacred was 'real' [...]. Reality was achieved through the imitation of celestial archetype, by giving material expression of that parallelism between macrocosmos and microcosmos without which there could be no prosperity in the world of man."

\section{Symbolism of the Centre in Islam}

Robert Heine-Geldern, in elaborating the parallelism between this idea of macrocosm and microcosms, states that

[a]ccording to this belief humanity is constantly under the influence of forces emanating from the direction of compass and from stars and planets. These forces may produce welfare and prosperity or work havoc, according to whether or not individuals and social groups, above all the states, succeed in bringing their lives and activities in harmony with the universe. ${ }^{7}$

According to a widespread conception of the ancient Semitic world, the world consists of a central element (as a starting ontological point around which units are ordered and organised). The world consists of a circular, central continent surrounded by seven annular oceans and seven annular continents. Beyond the last ocean - the seventh - the world is closed in by an enormous mountain range. Waide Jwaideh has argued that

some of the ancients have alleged that the earth is surrounded by water, and the water is surrounded by fire, and fire is surrounded by the lowest heaven, which in turn is surrounded by the second heaven ... and so on, to the seventh (heaven) and the latter is surrounded by the sphere of fixed stars .... ${ }^{8}$

According to Yāqūt (d. 1229), who reported narratives of thirteenth-century Muslim storytellers in Egypt, the earth is the central continent, and from its central point rises the mountain $Q \bar{a} f$, which in Muslim cosmology is the mountain range which encircles the world. According to popular belief, all mountains branch out from it and connect with it by subterranean branches and veins. Furthermore, it has 
been said that the mountain $Q \bar{a} f$ originated from the green corundum which serves as the support for the angel who holds the earth on his shoulders. Yăqūt added that the stability of the system is secured by animals such as the bull and the fish which in their turn are held by a sterile wind which is fastened to the Throne: i.e. the King (i.e. God). In this literature of cosmological symbolism, the mountain is a magical centre as an axis, at the top, middle, and the bottom of which were respectively placed the divine, human and nether worlds. Thus the mountain is an axis mundi, as Eliade has called it.

In addition to Yāqūt's representation of the world we should like to mention Islamic cosmological thinking, a hadìth-based genre of al-Suyūṭ̂̄'s (d. 1505) popular treatise al-Hay'at al-saniyyah fi 'l-hay'at al-sunniyah. ${ }^{9}$ The universe, according to al-Suyūṭ̂̀, is composed of "seven heavens, one spanned below the other". Al-Suyūṭ̂̄ added that,

according to the tradition, 'The heaven and earth were originally created from the primeval ocean and then sharply divided. [...] [t]he fish swims in water, which flows over stones; they in turn are carried by an angel, who stands on rocks, which are supported by the winds. ${ }^{10}$

Depending on cultural tradition, in the ancient Semitic world, many places were considered an axis mundi; "[o]ne of these was Golgotha, in the folklore of the Eastern Christians conceived as summit of the cosmic mountain upon which Adam had been both created and buried". ${ }^{11}$ Also in the Semitic world, one of the most dramatic examples of the cosmological centre is Jerusalem, "the very omphalos of the world, $[\ldots]$ and it was this symbolism which was subsequently transferred by Muslim hadìth to Mecca, a point which had been in existence according to a tradition preserved by Azraqi on the authority of one of Muhammad's contemporaries, the converted Jew Ka 'b al-Akhbar, for 'forty years before Allah created heavens and the earth'."12

The Ka bah is believed to be on the vertical axis directed to the Polestar, the centre of heaven; according to Wensinck, "the Polestar proves that the Ka'ba to be the highest situated territory on earth, for it (viz. the Ka'ba) is opposite the centre of heaven". ${ }^{13}$ This point, the Ka 'bah, is not only the central point of Mecca, but also the symbol of the navel of the earth. "Its ontological point is Mount Abu Qubays where never a repentant sinner had climbed it without being heard." ${ }^{\prime 14}$ At this mountain top as a referential point of Mecca, the communication between man and his Creator is to be held. In this same connexion we may also recall the tale of 'Abd-Allāh b. al- 'Abbās (d. c. 687-8) who, fearing that the unvoiced insinuation of heart (khawātir al-qalb) might yet be audible to Allah from a point in Mecca, prudently transferred his residence to Țầ'if, where he presumably hoped to be held responsible only for his more overt action and speech. ${ }^{15}$ Mecca is the holy city of the Muslim world in which thousands of Muslims meet annually and to which one fifth of mankind orient 


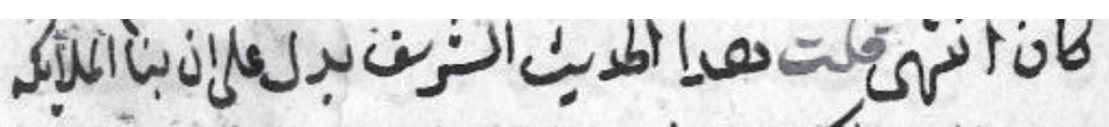

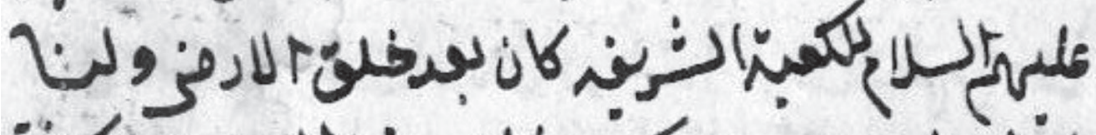

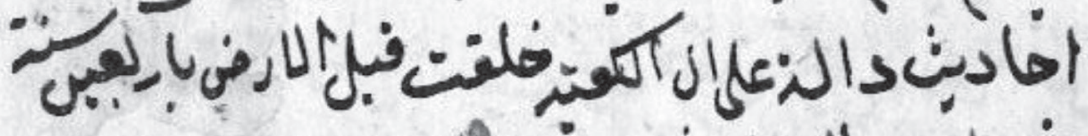

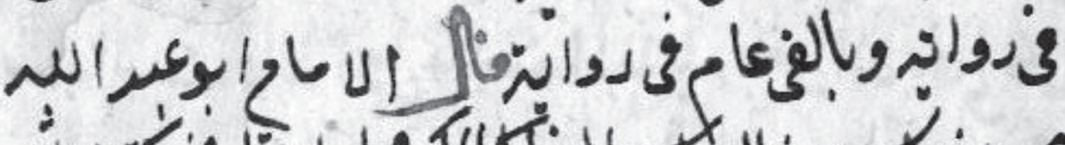

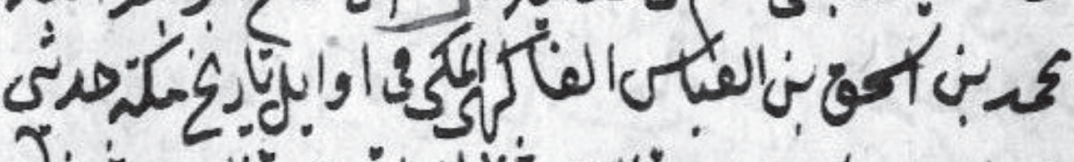

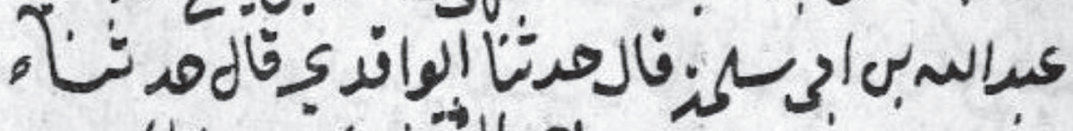

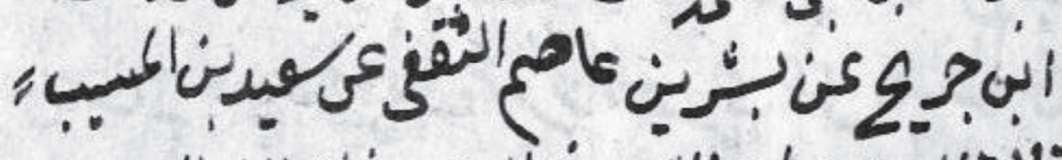

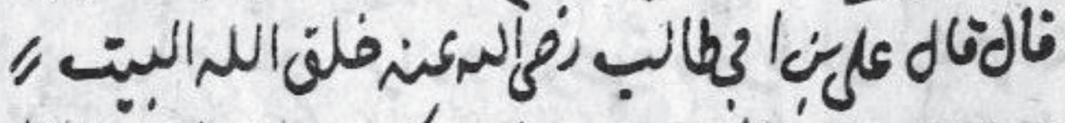

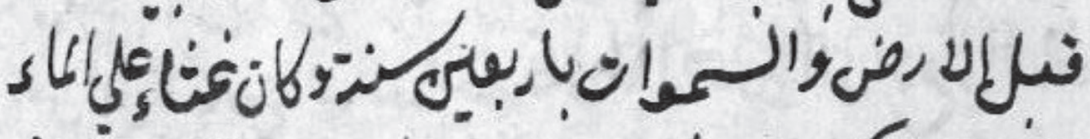

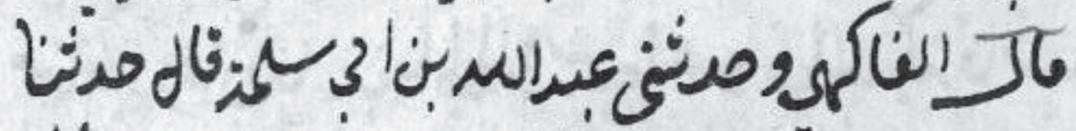

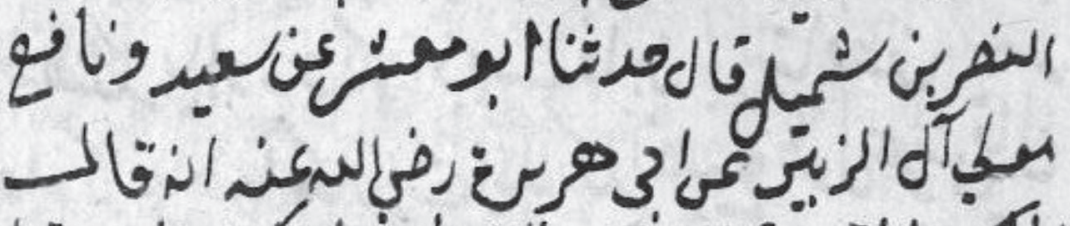

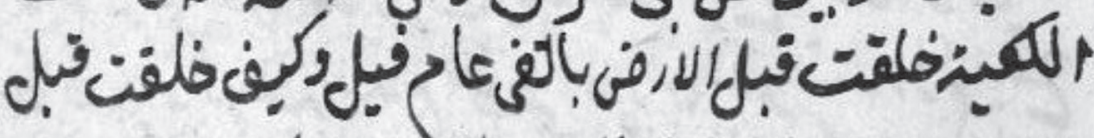

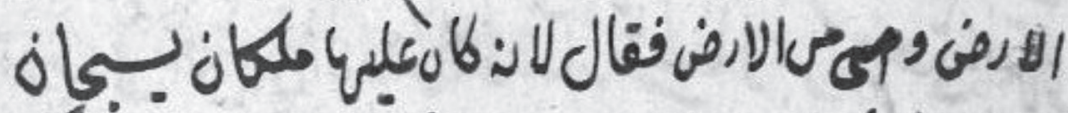

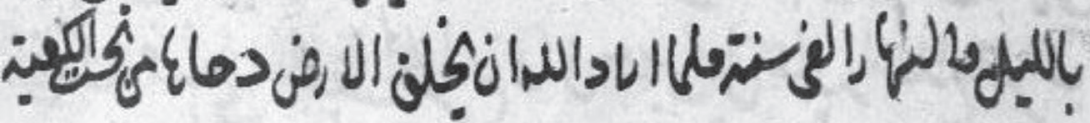

Figure 1 The celestial antiquity of the Ka'bah: page from a sixteenth-century Arabic manuscript on the Ka 'bah by Quṭb al-Dīn b. 'Alā' al-Dīn - citing the early text by al-Fākihī (d. c. 892), Ta'rīkh Makkah - which gives two reports from 'Alī b. Abī Țālib and Abū Hurayrah on the creation of the Ka'bah before that of the Earth. 
their prayers five times a day. The central idea here is that a configuration of the concept of the centre is manifested at different levels of life by means of evocation in order to make orientation possible. In essence, the manifestations of the centre of the world are various, as Eliade mentioned, "[w]hether that space appears in a form of a sacred precinct, a ceremonial house, a city, a world, we everywhere find the symbolism of the centre of the world". ${ }^{16}$

In the Islamic cultural tradition, the centre is based on an organising principle which transforms multiplicity into unity. As Seyyed Hossein Nasr puts it, "the sacred traditions although outwardly different are inwardly united into a centre which transcends all forms". ${ }^{17}$

Nasr also went on record to write on a certain geo-physical dimension of the concept of centre in Islam:

just as Islam is one of the 'middle ways' so too did its territory come to occupy - in fact it still occupies - the 'middle belt' of the globe, from the Atlantic to the Pacific. In this region, Islam came into contact with other civilisations, their philosophies and their sciences - so that the Islamic worldview is informed by the outlook and values of other great traditions. ${ }^{18}$

\section{The Development Process of the Prophet's Medina}

As to the conception of the city in the Islamic cultural tradition, this section offers a brief exposition on Medina - the 'City of the Prophet' - which is considered to be the first Muslim settlement following the consecration of the Holy City of Mecca.

During the decade of the Prophet's life in Medina (the former Yathrib), the city expanded enormously. The Emigrants (al-muhäjirūn), those who accompanied the Prophet from Mecca, settled around the Prophet's Mosque, which later formed the centre of the city. Consequently, life in its economic, social, religious, and political aspects was ordered around this central Mosque.

The traditional oral formulation states that when the Prophet travelled to Yathrib/ Medina in order to reside there, he did not want to locate by himself the site of his future dwelling, and he therefore left it to his she-camel to 'decide'. From then on, the area, designated as the dwelling and the main Mosque, became the centre of the city. ${ }^{19}$ This process is seen as an end to relativity and confusion. As Eliade puts it,

something that does not belong to this world has manifested itself apodictically and in so doing has indicated an orientation or determined a course of conduct [...]. This amounts to an evocation of sacred forms or figures for the immediate purpose of establishing an orientation in the homogeneity of space. ${ }^{20}$ 
In essence, the she-camel has played the role of mediator between the divine and the human world. Throughout the ancient world, extensive source material dealt with the participation of animals in the sacredness of space.

The Prophet's mosque and his dwelling in Medina were the starting point to make the territories surrounding them become habitable and hence become 'the world'. In other words, the mosque is seen as the sacred central pole by means of which communication with other worlds is ensured. This pole was the ultimate reference for organising the layout of the city.

Subsequently, the territories were consecrated by the Prophet who distributed them in the form of fiefs to people. These territories were known as the khittahs.

[...] from its root, the term khitțah seems to convey the idea of marking out with a line; its general meaning is ground occupied for the first time, a 'pitch', a holding; hence it comes to mean a site of any sort. In connection with Fustat (the Old City of Cairo), as with other towns surrounded by the Arabs, the sense is often connected spatially with a foundation. Thus, when a Mosque is described as khițtī, the meaning is that the original construction dated back till then. ${ }^{21}$

Khitțah also denotes the quarter in the city. Al-Balādhurī (d. 892) stated that following the erection of the mosque in Medina, the local 'Helpers' (al-anșār) gave up to the Prophet whatever extra land they had within their own khitttah (quarter). Yāqūt, in an account of the fiefs granted by the Prophet, gives the impression that the Prophet assumed chief responsibility for distributing land and settling people in Medina: ${ }^{22}$

When the Prophet arrived at Medina he granted the dür (house plots) and quarter to people. Thus, he marked a khițtah for the Banī Zahra in a part of the place behind the Mosque, [...] and granted Abdallah and Utbah the sons of Mas' ũd al-Hudhali their well known khițtah near the mosque, and granted Ṭalhah b. 'Ubayd-Allāh the site of his dawr, and for Abū Bakr al-Ṣiddīq the site of his dār (house) near the mosque. And he granted each of 'Uthmān b. 'Affān, Khālid b. al-Walīd, and al-Miqqad and others the sites of their dawr. ${ }^{23}$

As to the layout of areas for commercial streets, the bazaar (süq), the Prophet spatially arranged them to be within the city. The Prophet ordered that the $s \bar{u} q$ should be close to the mosque. In the view of El Hadhloul, "Ibn Shabbah's (d. 876) report that the Prophet choose Baqi al-Zubayr as the site of the Sug $[s \bar{u} q]$ but was forced to move it to its present place suggests that the Prophet wanted the Sug to be close to the Mosque." ${ }^{24}$ One of the principal commercial streets was also branched to the mosque. Medina's market was developed into specialised sūqs of "date sellers, fruit sellers, bakers, dryers, tailors, leather merchants, sellers of copper utensils, and smiths". ${ }^{25}$ 
As to Medina's fortifications, a wall surrounding it was erected following the formative period of the city. According to Jairazbhov,

[t]his wall was rebuilt by the governor of the city Mohammed Ibn Ishaq in 850 A.D. The wall was again rebuilt in 1145 A.D. by the Sultan of Mosul, and Nuraddin ordered an outer wall to be erected in 1161 A.D. In 1183 A.D. Ibn Jubayr noted that Medina was double walled and had four gates one facing the other in the opposite wall. ${ }^{26}$

Medina was conceived within the spatial configuration that consists of a central element around which other elements are organised around; a reminder of the divine city as conceptualised in pre-Islamic time. The central element consisted of the Prophet's house, adjacent to the central Mosque.

The mosque with its Bāb al-Rahmah or 'Gate of Mercy' denotes - within the city - the heaven from which the cosmological force (consecrated goods) of the universe overflowed into the city and the entire region through the city gates. Being the dwelling of the Prophet and the spatial key of the layout of the city, the Mosque was considered the abode of the divine microcosm on earth. In other words, it was the locus of the axis mundi that united the city with the divine macrocosm. The Prophet was considered the khaliffat Alläh, God's vicegerent on earth. According to S.H. Nasr, this was so "because man is the vicegerent of the Creator that things in this world are ordered on his behalf, and he is given power over them". ${ }^{27}$ During the period following the Prophet's ministry, the heads of government of Medina and other cities bore the title of 'caliph', and to the people they were the 'successors' of Muhammad in his capacity as worldly ruler.

All the early Islamic cities established after Medina, were built in varying degrees of approximation to this ideal city of Medina. They were conceived as microcosms of the divine cosmos. Numerous cities were founded during the territorial expansion of Islam. Different locations (e.g., Kufa and Basrah in Iraq, Kairouan in Tunisia, or Qazwin in Iran) were used for the foundation of these cities. Some of these locations were known as mawāqīt (plur. of $m \bar{\imath} q \bar{a} t$ ). The term mawāqit is used to denote the 'stations' which pilgrims visit to assure themselves a state of ritual consecration. In the words of Wadie Jwaideh,

These locations define the nature of cities as places of pilgrims and visitors and domiciles of the companions and followers of the Prophet tomb-shrines of the saints and the pious, the scene of expeditions of Apostles, and the territories conquered by imams, the orthodox caliphs. ${ }^{28}$

Perhaps the most famous instance of a major Islamic city consciously representing itself as an 'image of world centre' was the foundation of Baghdad as the new centre of Islamic imperial rule by the second Abbasid ruler Abū Ja far al-Manșūr (r. 754-775). His famous Round City was built during 762-766 and became known 
as Madinat al-Saläm or the City of Peace (Figure 2). With its four gates toward the four major areas of the empire, and the caliphal palace in the exact centre with its legendary cupola over the caliph's audience hall crowning al-Manșūr's Gold Palace surmounted by a gilt green dome 120 feet ( 80 cubits) high topped with a mechanical device, this became an explicit symbol of the global position Islam claimed in both territorial and spiritual terms. ${ }^{29}$

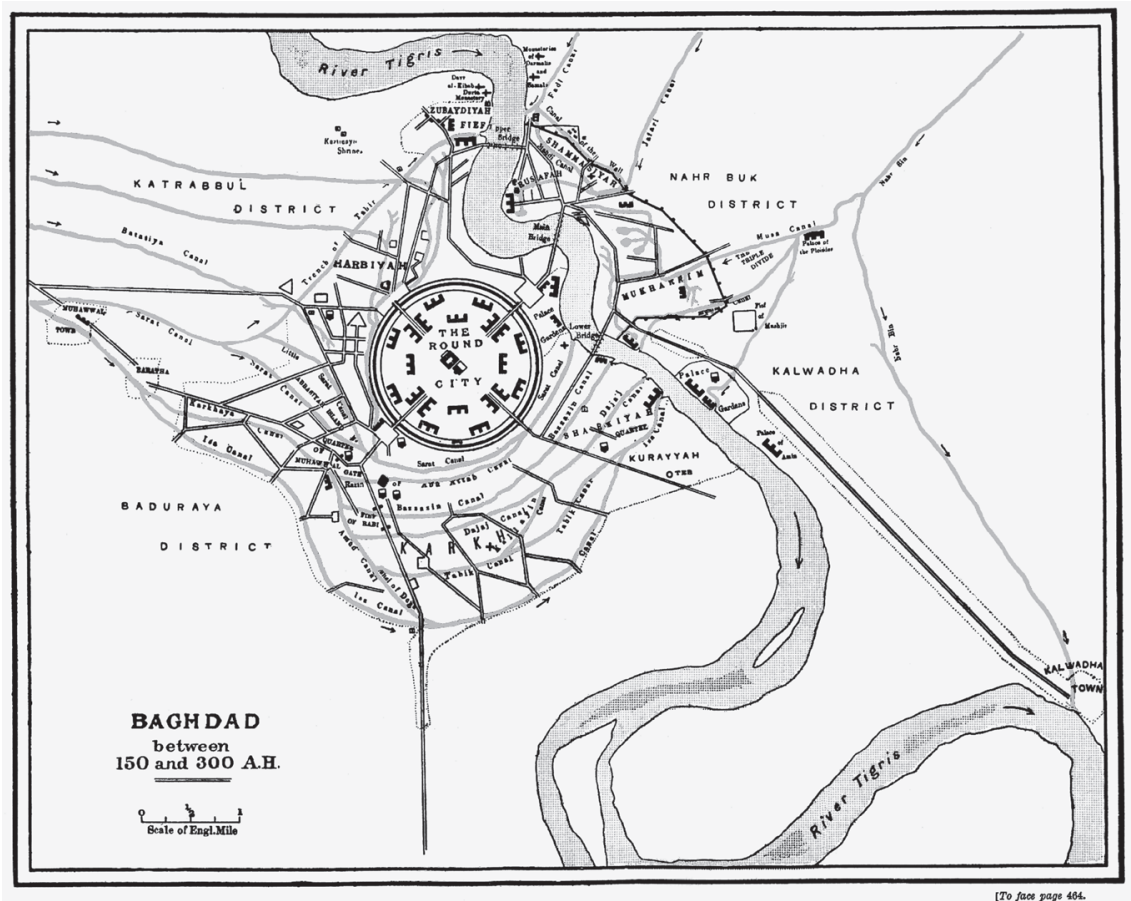

Figure 2 The city of Baghdad between 767 and 912. The 'Round City' of caliph al-Manșūr, the largest urban centre in the Abbasid empire from 765 until 1258 when it was destroyed by the Mongol Hulagu Khan. The city grew rapidly in size from its founding until it covered around 100 square kilometres.

Source: William Muir, The Caliphate: Its Rise, Decline, and Fall from Original Sources, rev. by T.H. Weir (Edinburgh: John Grant, 1924), map facing p. 464, available online at http://en.wikipedia.org/wiki/ File:Baghdad_150_to_300_AH.gif, accessed on 24 February 2011).

By founding these cities, the caliphs or imams were mediators between human and divine worlds. The process of laying out and building the city started with elements such as the mosque, the palace of the ruler or the king and the market. It was the ruler's task to facilitate worship by constructing religious buildings. This was also conceived as magically producing good results. The benefits to the 
city and kingdom took visible form in the demarcation of fortifications such as armouries, ramparts, moats and gateways. The capital, protected by fortifications, was conceived to be located at the centre of the kingdom and was the territory of effective contact between the ruler or the king and the kingdom.

Moreover, the capital city played a central role in the kingdom like the sun's central role in the universe. The principles of astrology which the 'Brethren of Purity' (Ikhwān al-Safā') - the tenth-century Iraq-based esoteric society who expounded their teachings in an epistolary style in an encyclopaedic compendium - described are the same as those used by the Muslim astrologers:

God has placed the Sun at the centre of the universe just as the capital of a country is placed in its middle and the ruler's palace at the centre of the city. ${ }^{30}$

\section{Unravelling the Meaning of the Centre in Islam: Some Conclusions and Recommendations}

Today, for most policy makers and architects of the Islamic world, the image of a centre for the city conjures up an image of a commercial centre, office spaces and shopping malls. There is nothing inherently wrong with such an image of a modern city centre, for commercial centres existed in pre-modern cities, but the problem is when that kind of modern city centre is understood to be the only conceivable one.

The literature of social space in general when treating city centres, has focused on a specific type of city, namely, the pre- or post-industrial western metropolis, a focus that has amounted to a neglect of the overwhelmingly large part of the human urban experience. In other words, the Islamic cultural tradition of the centre is based on the homology in which ritual, space, words, action, person and object come to be a single order of a totality in a unitarian ideology: al-tawhìd. This integrated belief has been fragmented into separate units, while its integral symbolism has been disintegrated into pieces and elements, in the words of Akkach,

with each element assuming a world of its own. The core metaphysical order that used to unite the whole has disintegrated. As a result, cosmological ideas have lost their immediacy in people's lives and spatial practice while being complexified with layers of impenetrable mathematics. ${ }^{31}$

Remnants of that integral symbolism have survived in Islamic culture. In unravelling the meaning of the Islamic centre today,

- one needs to understand not only the relationship that man has with his built environment but also the Islamic view of the human condition including man's attempt through the ordering of space to attain prosperity. 
- The textual expertise and the study of the insights of Muslim writers such as Yāqūt and al-Suyūṭ̂ constitute "a complex web of meanings and intricate patterns of correspondence that once govern the world and materialise the order inscribed in the divine exemplar". 32

- This knowledge is crucial for the reinterpretation of architectural education and the production of the built environment in the Islamic world today, and should thus be explored further by interdisciplinary Muslim scholars.

\section{Notes}

1. Mircea Eliade, The Sacred and the Profane: The Nature of Religion, tr. from the French by Willard R. Trask (New York: Harcourt, Brace and World, Inc., 1959), 22.

2. Sudhir Kakar, The Inner World (Oxford: Oxford University Press, 1978), 15.

3. Otto von Simson, The Gothic Cathedral: The Origins of Gothic Architecture and the Medieval Concept of Order (New York: Harper, 1964), xviii.

4. Roy Wagner, "The Liminal Dynamo: Culture as the Tension of Neocortical Expansion”, paper presented at the American Anthropological Association Symposium, Denver CO, November 1984.

5. Von Simson, The Gothic Cathedral, 24.

6. Paul Wheatley, The City as Symbol: An Inaugural Lecture Delivered at University College London (London: H.K. Lewis \& Co Ltd, 1967), 9-10.

7. Robert Heine-Geldern, "Conceptions of State and Kingship in Southeast Asia", Far Eastern Quarterly 2 (1942), 15.

8. Waide Jwaideh (tr., annot.), The Introductory Chapter of Yakut's Mu'jam Al-Buldan (Leiden: E.J. Brill, 1959), 33.

9. Samer Akkach, Cosmology and Architecture in Premodern Islam: An Architectural Reading of Mystical Ideas (Albany NY: State University of New York Press, 2005), 2.

10. M. Anton Heinen, Islamic Cosmology: A Study of As-Suyūțì's al-Hay'a as-sanīya fì l-hay'a as-sunniya, with Critical Edition, Translation, and Commentary (Beirut: Orient-Institut der Deutschen Morgenländischen Gesellschaft; Wiesbaden: F. Steiner Verlag, 1982), 86.

11. Wheatley, The City, 15.

12. Ibid., 15.

13. Akkach, Cosmology, 183; citing A.J. Wensinck's classic article on "The Navel of the World".

14. Wheatley, The City, 16.

15. Ibid., 16 .

16. Eliade, The Sacred, 37.

17. Seyyed Hossein Nasr, "Introductory Preface", in: Keith Critchow (ed.), Islamic Patterns: An Analytical and Cosmological Approach (London: Thames and Hudson, 1976), 6.

18. Seyyed Hossein Nasr, Science and Civilization in Islam (Cambridge MA: Harvard University Press, 2003), 30.

19. Salah El Hadhloul, "Tradition, Continuity and Change in the Physical Environment: The Arab-Muslim City", PhD dissertation, Harvard University, 1975.

20. Eliade, The Sacred, 27.

21. A.R. Guest, "The Foundation of Fustat and the Khittahs of that Town", Journal of the Royal Asiatic Society (January 1907), 57.

22. El Hadhloul, "Tradition", 31.

23. Ibid.

24. Ibid., 33 .

25. Ibid., 34 . 
26. R.A. Jairazbhov, Art and Cities of Islam (Bombay: Asia Publishing House, 1964), 57. For detailed information on the transformation of the built space of Medina see Nūr al-Dīn 'Alī b. Aḥmad al-Samhūdī, Wafā' al-wafā bi-akhbār Dār al-Muștafāa, ed. Muḥammad Muḥyī al-Dīn 'Abd al-Ḥamīd (Cairo, 1955, 4th repr. Beirut, 1981).

27. Seyyed Hossein Nasr, An Introduction to Islamic Cosmological Doctrines (London: Thames and Hudson, 1978), 150.

28. Jwaideh (tr., annot.), The Introductory Chapter, 4.

29. Jacob Lassner, The Shaping of 'Abbāsid Rule (Princeton NJ: Princeton University Press, 1980), 163-83. For the cosmological significance of the 'Round City' of caliph al-Manșūr consult C. Wendell, "Baghdad: Imago Mundi and Other Foundation Lore", International Journal of Middle Eastern Studies 2 (1971), 99-128.

30. Nasr, An Introduction, 77.

31. Akkach, Cosmology, xix.

32. Ibid., xxii. 